Georgetown University Law Center

Scholarship @ GEORGETOWN LAW

2009

\title{
Is Law an Economic Contest? French Reactions to the Doing Business World Bank Reports and Economic Analysis of the Law
}

Anne-Julie Kerhuel

Georgetown University Law Center, ak625@law.georgetown.edu

Bénédicte Fauvarque-Cosson

University Panthéon-Assas

This paper can be downloaded free of charge from:

https://scholarship.law.georgetown.edu/facpub/372

57 Am. J. Comp. L. 811-830 (2009)

This open-access article is brought to you by the Georgetown Law Library. Posted with permission of the author. Follow this and additional works at: https://scholarship.law.georgetown.edu/facpub

Part of the Comparative and Foreign Law Commons, International Law Commons, and the Law and Economics Commons 


\section{GEORGETOWN LAW Faculty Publications}

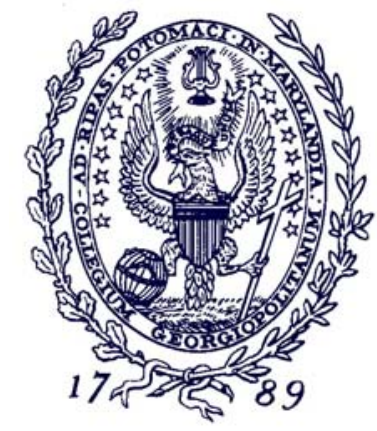

Georgetown Business, Economics \& Regulatory Law Research Paper No. 10-10 June 2010

\section{Is Law an Economic Contest? French Reactions to the Doing Business World Bank Reports and Economic Analysis of the Law}

57 Am. J. Comp. L. 811-830 (2009)

\author{
Anne-Julie Kerhuel \\ Visiting Researcher \\ Georgetown University Law Center \\ ak625@law.georgetown.edu
}

Bénédicte Fauvarque-Cosson

Professor of Law

University Panthéon-Assas

This paper can be downloaded without charge from:

Scholarly Commons: http://scholarship.law.georgetown.edu/facpub/372/

SSRN: http://ssrn.com/abstract $=1623446$ 


\section{BÉNÉDICTE FAUVARQUE-COSSON AND ANNE-JULIE KERHUEL*}

\section{Is Law an Economic Contest? French Reactions to the Doing Business World Bank Reports and Economic Analysis of the Law}

The economic analysis of law has provoked strong reactions among French academics, in particular since 2004 when the first of the Doing Business reports was published. French jurists have joined forces to expose the methodological limits inherent to these reports, which rated France a long way behind other legal systems allegedly more able to facilitate business.

In its first part, this article examines the various reactions to these reports, almost all of which were published in French only.

In the second part, the focus is on the position of economic analysis in French law, its role, and, in particular, the impact of the Law and Economics school on comparative law in France. It also takes a look at the studies that followed, especially the legal origins thesis. The article shows that the various approaches are complementary and that economic analysis, without supplanting the traditional comparative approach, has considerable use. At a time when the globalization of business relationships is leading more than ever to a competition between the various national laws, comparatists should include more of this dimension into their field of study. Comparatists can also take a cue from economists on how to improve the relevance and the influence of their research in the public debate.

The first World Bank Doing Business report, entitled Doing Business in 2004: Understanding Regulation, was like an electric shock to the French (and French related) legal community. The debate about the economic efficiency of law, which had not been particularly prominent in France until then, suddenly became energetic. France, a country steeped in its legal tradition, was rated forty-fourth (behind Jamaica, Botswana, and Tonga) and considered one of the legal sys-

* Bénédicte Fauvarque-Cosson is a Professor at University Panthéon-Assas and the Vice President of the International Academy of Comparative law, Secretary General of the Société de législation comparée. Anne-Julie Kerhuel, Ph.D. of the University Aix-Marseille. We thank Ralf Michaels for his invitation to participate in this debate and for his comments on the preliminary versions of this contribution. 
tems least conducive to economic growth. At the same time, the merits of common law countries were emphasized strongly in terms of support for the principle of market forces over state intervention. The underlying perception was that codified laws are inferior when compared with common law. Since then, France's rating in the Doing Business reports has slowly improved. Nonetheless, even in 2009, France was still in thirty-first place, behind Israel, Latvia, and Lithuania, and just slightly ahead of South Africa and Azerbaijan. The reasons for the low ranking are explained in the reports. In 2008 and 2009, France, by contrast, was ranked sixteen in the Annual Report of the World Economic Forum.

Could it be that the common law is more efficient than the civil law? ${ }^{1}$ It is unusual in France to adopt such an angle when contrasting the French civil law tradition with the common law. The analysis of both traditions had remained scientific and academic so far. But now, following the Doing Business reports, it took the form of a vigorous defense, not merely of the French legal tradition, but of law pitched against economics, and of legal diversity as an expression of cultural diversity. The economic analysis of law has not been rejected outright- to the contrary, as we will see, French literature on the subject has been thriving, in part thanks to the shock caused by the Doing Business reports and the concept of economic attractiveness as a characteristic of law has become accepted, even in academic circles. Yet, an in-depth study of the relationship between the economic analysis of law and comparative law in light of these reports is still lacking. Such a study should be envisaged to promote an interdisciplinary approach to comparative law as well as to cultural diversity. So far, the example of these annual reports is quoted by comparatists, at best, to confirm the traditional view that the comparative study of law should be carried out with traditional methods based on reliable data. $^{2}$

\section{Doing Business Reports: "Le choc"}

"French law was thus brutally reminded of the requirement of efficiency by American schools of economic analysis of development factors" (Guy Canivet about the first Doing Business report (2004). ${ }^{3}$

The Doing Business reports played a crucial role in alerting the French legal community to the fact that law has become an instrument of economic domination, that there exists a real market for law,

1. In French, the expression "droit de tradition civiliste" or "droit romanogermanique" is often used to refer to a legal system based on written codes.

2. Yves-Marie Laithier, Droit comparé, Dalloz, 2009, p. 16.

3. Guy Canivet, President of the Cour de cassation, official speech for the "rentrée solennelle" of the Cour de cassation, January 2005. 
and that in a number of sectors, we need to reform our law, ${ }^{4}$ if only to "sell" it better. ${ }^{5}$

In order to understand the nature of the debate, a short presentation of the Doing Business report will follow together with an account of the various reactions among all legal professions and an analysis of the main arguments presented by scholars and practitioners. Particular attention will be paid to the contributions of participants in a group specifically constituted within the "Association Henri Capitant des Amis de la culture juridique française" (friends of French legal culture.)

\section{A. Brief Presentation of the Reports}

The Doing Business reports are based on factual information concerning laws and regulations in force. They deal with topics such as the time and cost of meeting regulatory requirements to register a business, rigidity of employment law or procedures to enforce a contract. They also investigate the efficiency of government institutions, including business registries, courts, and public credit registries. The methodology builds on detailed information about regulations that are considered relevant to identifying specific problems and designing reforms. Since 2004, the indicators have been scrutinized and modified but the general aim has remained the same.

4. For a critical assessment of the economic attractiveness of French law, see Xavier Lagarde, Brèves réflexions sur l'attractivité économique du droit des contrats, 2005 Recueil Dalloz 2745.

5. See L'analyse économique du droit des contrats: outil de comparaison, facteur d'harmonisation, 2005 Gazette du Palais $\mathrm{n}^{\circ}$ 68-69; Marie-Anne Frison-Roche, Les grandes questions du droit économique. Introduction et documents (collection Quadrige, PUF 2005); Olivia Dufour, Le droit français, un bon produit d'exportation!, 973 Option Finance 20 (25 March 2008); Jean-Marc Baïssus, Nous n'avons pas à craindre la compétition des systèmes juridiques, 2007 JurisClasseur Périodique, édition générale, $\mathrm{n}^{\circ}$ 24, I, 162 (13 June 2007); Michel Bénichou, Il faut créer des spécialisations liées au marché et à la demande et non au droit pur, 2005 JurisClasseur Périodique, édition Générale, n 38, I, 167 (21 September 2005); Bertrand Du Marais, Attractivité économique du droit-le droit français peut-il survivre dans la compétition internationale?, 2008 Droit et patrimoine, $\mathrm{n}^{\circ} 170$, p. 38; Bertrand Du Marais, De Koror à Palikir: à la recherche du paradis du droit des affaires, 2006 Recueil Dalloz 1110; Jean-Marc Baïssus, La concurrence des systèmes juridiques est en marche!, Petites Affiches, 28 February 2008, $\mathrm{n}^{\circ} 43$, p. 3; see also the documents from the Assises des opérateurs du droit continental of 8 October 2008 on Le droit, un atout dans la compétition économique internationale?, 2008 Revue Lamy du droit des affaires, $\mathrm{n}^{\circ} 32,80$.

This analysis has extended to administrative law, see Le droit administratif français est-il encore exportable?, La Semaine Juridique Administrations et Collectivités territoriales $\mathrm{n}^{\circ}$ 16, 16 April 2007, $2094 \mathrm{~s}$.

On the predicted decline of the economical analysis of law in the United States and regarding criticism of the hegemony of American law partly due to this doctrine, see Ugo Mattei, Analyse économique du droit et hégémonie de la pensée juridique américaine: un essai sur l'ascension et la chute du prestige culturel, Gaz. Pal. 2005, $\mathrm{n}^{\circ}$ 68-69 p. 37 and following. 
The whole project aims at motivating reforms through country benchmarking. The 2004 report was the first publication of an annual series which studies the determinants of private sector development. In this report, five topics were analyzed: starting a business, hiring and firing workers, enforcing contracts, securing credit, and closing a business. Over the next few years, Doing Business extended the coverage of topics (for instance, Doing Business in 2005 added three new sets of indicators: showing the regulations an entrepreneur faces when registering property, protecting investors, and dealing with business licenses). The stakes are high: these reports, read worldwide, enjoy a huge success and have been used as models for other reports ${ }^{6}$ as well as for legislative reforms and, presumably, for investment decisions.

The Doing Business reports assume that the quality of the laws and regulations that govern business play a decisive role in economic growth. Based on the performance observation of a number of legal systems, they aim to demonstrate that the heaviest regulations produce the worst results because they are usually associated with inefficiency within public institutions, long delays in reaching decisions, high costs of administrative formalities, lengthy judicial proceedings, higher unemployment and more corruption, less productivity, and lower investment.

The 2004 report arrives at the following conclusions, all reported in the overview at the beginning of the report:

- Poor countries regulate business the most, and, according to the Report, "Common law countries regulate the least. Countries in the French civil law tradition the most. However, heritage is not destiny."

- Heavier Regulation Brings Bad Outcomes and, according to the Report, "Heavier regulation is generally associated with more inefficiency in public institutions and more unemployed people, corruption, less productivity and investment, but not with better quality of private or public goods."

- "One Size Can Fit All"-in the Manner of Business Regulation.

6. On October 1, 2008, the IFC, International Finance Corporation, subsidiary of the World Bank, which has published the Doing Business reports since 2004, published the first report dealing with the ability to do business in landlocked countries: Doing Business in Landlocked Economies 2009, available at http://www.doing business.org/features/Landlocked2009.aspx. For a critique, see Arnaud Raynouard, Doing Business in Landlocked Economies, une déclinaison particulière des rapports Doing Business, available on the website of the Fondation pour le droit continental: http://www.fondation-droitcontinental.org. 
In an attempt to correct errors in the 2004 report, the 2005 report discusses the founding of an enterprise and, rates France among the "top ten reformers," chapter 2. This rating was based on one specific statute but as noted by some French authors, the role of that particular statute-which would have favored the creation of 14,000 enterprises-was certainly over-rated. ${ }^{7}$ The 2006 report saw France relegated to 44 th place, behind Jamaica. The economic press coverage relayed the affront and observed that this ranking stood in significant contrast with France's economic and political power worldwide. In the 2007 report, France gained a few places, ranking 35th, just after Armenia. The 2008 and 2009 rankings were slightly more favorable: 32nd after Puerto Rico, and 31st after Israel, Latvia, and Lithuania.

\section{B. Reactions}

To appreciate the forcefulness of the French reactions, it should be recalled that France has a strong tradition of legal export, deeply embedded in the consciousness of lawyers. ${ }^{8}$ The bicentenary of the Civil Code, celebrated the same year as the first publication of the Doing Business reporting a large number of countries throughout the world, illustrated this perfectly. This deeply rooted tradition of legal export may have made it particularly difficult to accept that French law should be affected by international influence, and to conceive of French law in terms of legal transplants, reciprocal fertilization and hybridization. However, these historical and cultural reasons alone do not completely explain the French reaction, especially when bearing in mind that the forging of the European Union had already caused significant changes in French mentality. ${ }^{9}$

The multitude and vigor of the French reactions must also be explained, after the initial shock, by the view that the disappointing ranking of the French legal system was based on inaccuracies and exaggerations in the first Doing Business report. It seemed particularly unacceptable to suffer the imposition of values which underpinned this report, and which were foreign to those upon which French society and its whole legal system were built. ${ }^{10}$ In addition,

7. On this point, see Association Henri Capitant des amis de la culture juridique française, Vol. 1, Les droits de tradition civiliste en question. A propos des rapports Doing Business (éd. SLC, 2006), p. 41.

8. See L'influence internationale du droit français, Rapport du Conseil d'Etat (Olivier Dutheillet de Lamothe, Marie-Aimé Latournerie eds., Documentation française, 2001), available at http://www.ladocumentationfrancaise.fr/rapports-publics/ 014000702/index.shtml; Bénédicte Fauvarque-Cosson and Sara Patris-Godechot, Le Code civil face à son destin, Documentation française, 2006.

9. Bénédicte Fauvarque-Cosson and Sara Patris-Godechot, op. cit.

10. Yves Lequette, D'un centenaire à l'autre (1904-2004) in Yves Lequette et Laurent Leveneur (dir.), 1804-2004 Le Code civil, un passé un présent un avenir, Paris, Dalloz, 2004, p. 19 s., sp. p. 35. 
the methodology adopted by the reports and its results were, and remain in part, deeply questionable despite definite improvements since 2004.

The French reactions were therefore severe, but they were also constructive. On the one hand, they forced the World Bank to revise some of its assertions, in particular, the idea of "one size fits all," emphasized in the 2004 report, which disappeared from the subsequent reports. On the other hand, they motivated France to modernize its law, and more fundamentally still, its ways of thinking. The French political and legal community immediately engaged in efforts to restore the position of French law in the field where it had been attacked by the World Bank, i.e., in the area of economic efficiency.

Already in 2004, the Paris Bar organized a conference in Washington entitled "The American and French Legal Systems: Contrasting Approaches to Global Business."11 One year later in Paris, the Bar held a large event, named "Paris-Place of Law," bringing together members of the French government (including Christine Lagarde, Minister for Trade, now the Economy and Finance Minister), representatives from the World Bank (both vicepresidents of the World Bank, Roberto Danino and Michael Klein), representatives from other international institutions, as well as judges, academics, and others.

The Doing Business reports have influenced the French legal profession's views of the future. In April 2009, a Commission presided over by a lawyer, Maître Jean-Michel Darrois, delivered an insightful report on the legal profession to the French President. ${ }^{12}$ Even if this was not a direct answer to the Doing Business reports, there is a link between the two: French president Nicolas Sarkozy personally conferred the task to Maître Darrois by a letter, in which he explained the purpose of such a report and emphasized that French lawyers (avocats), who have expanded their field of action, are now more than ever faced with the international competition that exists between legal systems. The letter adds that efficiency and legal

11. The American and French Legal Systems: Contrasting Approaches to Global Business, Lamy, 2005. This conference was held under the auspices of the President of the French Republic, Jacques Chirac, in presence of the Ambassador of France to the United States (Mr. Jean-David Levitte), the French Minister of Justice (Mr. Dominique Perben), the Vice President and General Counsel of the World Bank (Mr. Roberto Danino), the French Deputy Minister of Justice (Mme. Nicole Guedj), a Justice of the Supreme Court of the United States (The Honorable Stephen Breyer), academics, bankers, lawyers, and many other practitioners. The conference dealt with these three main topics: balancing private initiative and pubilc regulation; contribution of French Law to arbitration and codification; and adapting to the economic environment and to the international context.

12. Rapport sur les professions du droit, March 2009 ("Darrois report"), available at www.justice.gouv.fr/art_pix/rap_com_darrois_20090408.pdf. 
efficacy have become major goals for our economy. ${ }^{13}$ Maître Darrois' report contains a number of proposals aimed at redefining the mission of lawyersthrough the creation of a "broader legal profession" and by reinforcing the influence of the French legal system abroad, following the Anglo-American model.

The notaries have been particularly affected by the Doing Business reports, mainly because the reports criticize the French way of dealing with the transfer of property. The notaries took action and approached the World Bank on several occasions, and in September 2006, the President of the Conseil Supérieur du Notariat (the body representing the French notaries) wrote a letter to the French Prime Minister to express his disagreement with the assertions of the 2007 Report. ${ }^{14}$ French notaries take issue essentially with the report's evaluation of the law applicable to the transfer of real property, in particular the assertion that it causes delays in sales transactions. They correctly explain, that in France, the acte authentique de vente, established and signed by the vendor and the purchaser as well as by the notary, results in the immediate transfer of real property with all the consequences attached to such a transaction. On the occasion of the XXVth Congress of the International Union of the Latin Notariat (Madrid 2007), the importance of the seventy-five notariat members of the Union was affirmed, as was the concept that a notarized act is a legal instrument which combines equity with functionality, contrary to what the Doing Business reports say. ${ }^{15}$

The French judiciary also felt concerned. Not only did the President of the Cour de cassation make reference to the Doing Business reports in his speech of January 2005 at this Court (France's highest court in private law matters), ${ }^{16}$ but the Court has also investigated the economic impact of one particular court decision. ${ }^{17}$ Concern was also shown at the administrative courts. ${ }^{18}$ Furthermore, a series of

13. The full text of this report, including the letter of President Sarkozy, can be found on http://www.justice.gouv.fr/art_pix/rap_com_darrois_20090408.pdf, sp. p. 125.

14. Http://www.notaires.fr/notaires/notaires.nsf/V CD_PUB/SMSI-6TED88.

15. Cyril Nourissat, Le Notariat: institution mondiale . - XXVe Congrès de l'Union internationale du Notariat latin Madrid, 3-5 octobre 2007, 2007 La Semaine Juridique Notariale et Immobilière, 1307.

16. Id.

17. In a decision of its Mixed Chamber of 23 November 2004, 4 cases, Bull. civ., $\mathrm{n}^{\circ}$ $4, \mathrm{n}^{\circ}$ 01-13.592, the Cour de cassation categorized life insurance as a simple investment operation and rejected its recharacterisation as a capitalization contract, with the consequence that article 1121 of the Code Civil, which imposes certain conditions for the validity of a stipulation pour autrui that would prevent the broader development of life-insurance, is inapplicable. The decision followed an exceptional round of consultations involving notaries, insurers, the Ministry of Economy, Finance and Industry as well as the Ministry for Justice.

18. On this point, see Jean-François Calmette, L'évolution de la prise en compte de l'analyse économique par le juge administratif, 2006 Droit Administratif, $\mathrm{n}^{\circ}$. 7, Etude 14 (July 2006). 
roundtable sessions was inaugurated in 2004 by the Regulations Chair of Sciences Politiques (the Political Studies Institute of Paris, one of France's elite venues of higher education) and the Cour de cassation, devoted to the economic analysis of law; it led to the publication of various articles and books, one dedicated to banking and another offering more general reflections on law, economics, and justice. ${ }^{19}$

Among the reactions the World Bank reports provoked in France, one must also mention the launch, by the former French Minister of Justice M. Dominique Perben, of an international research group, entitled "The Economic Attractiveness of Law," as well as the establishment of the Foundation for Continental Law, which adopted a new program with similar objectives once the mandate for the "Economic Attractiveness of Law" had expired.

The "Economic Attractiveness of Law" (AED) was a research program designed to demonstrate the effectiveness of certain legal instruments created by written law, in particular in the French legal tradition. For this purpose, it aimed to show that the diversity of legal instruments available to the economic sector could lead to greater efficiency, since those instruments are designed to provide solid legal certainty, so that they may be more favorable to economic transactions than a hasty standardization. This program mobilized around a hundred jurists and economists working on approximately ten projects and created a new dynamic of interdisciplinary research projects investigating the relationship between economics, law and institutions. The scientific coordinator and head of the project was Bertrand du Marais, a member of the Conseil d'Etat. The program was supervised by a scientific council of thirty internationally renowned scientists, jurists, and economists, whose task was to check the coherence of the projects and the scientific quality of the results. Among the books and articles that were published, one is entitled "Indicators in Order to Measure Law? The Methodological Limits of the Doing Business Reports." 20 It examines the reliability of indicators used to measure the economic attractiveness of law and delivers a critical analysis of the specific indicators used in the Doing Business

19. Guy Canivet, Bruno Deffains, Marie-Anne Frison-Roche (dir.), Analyse économique du droit: quelques points d'accroche, Petites Affiches 19 May 2005, ${ }^{\circ}$ spécial 199; Les banques entre droit et économie (Marie-Anne Frison-Roche, Jean-Paul Betbèze, Christian Bordes, Guy Canivet eds., LGDJ, 2006); Droit et économie des contrats (Christophe Jamin ed, LGDJ 2008).

20. Bertrand du Marais, Didier Blanchet, Anna Dorbec, Des indicateurs pour mesurer le droit? Les limites méthodologiques des rapports Doing Business (Paris, La documentation française, Collection Perspectives sur la justice, 2006). See also Agences de notation, immobilier et contrats publics. Contributions sur l'attractivité économique du droit (Bertrand du Marais ed., Paris, La Documentation française, Collection Perspectives sur la justice, 2007); Réformes du droit économique et développement en Asie (Judith Gibson, Bertrand du Marais eds., Paris, La Documentation Française, Collection Perspectives sur la justice, 2007). 
reports. It also contains comments on the drafting and use of the questionnaires, with suggestions for improvement.

The Fondation pour le droit continental (Foundation for Continental Law), was launched in 2005 by the French Ministry of Justice, partly as a reaction to the World Bank Doing Business reports. The governing bodies of the French legal profession, together with public institutions, supported the Foundation. Academics from all over the world (even from common law countries such as the United States, Canada, and Australia) are involved as members of the scientific council. With the support of this Foundation, the legal professions organized an international conference entitled "Continental Law and the Global Financial Crisis - Contributions Towards a Better Regulation" in May of 2009. It was held at the World Bank, in Washington, D.C., to introduce the legal professions' expertise to an audience of American decision-makers. A second day was devoted to specific topics such as the management of public-private partnerships and the position of continental jurists with respect to the World Bank's Doing Business reports. ${ }^{21}$

In September 2007, the Foundation took over a new research program: "Think Tank Economic Efficiency of Law (2eL)." The program, directed by Professor Arnaud Raynouard, ${ }^{22}$ initiated a series of research projects concerning the relationship between law and economics. The research results appear in a regular essay review series. ${ }^{23}$ The group also analyzes researches possible new indicators of economic efficiency, in particular, an index measuring the certainty legal systems provide.

Over the last few years, a large number of academics and practitioners have taken issue with the Doing Business reports on a number of points and criticized the Law and Economics school which inspired them. ${ }^{24}$ Some critics established a list of performance instru-

21. The full program of the event can be found on our website, with all the participants' contributions and a summary of the debates. http://www.fondation-droit continental.org/6.aspx?sr=623; see also http://www.avocats-conseils.org/programme_ washington1.pdf.

22. See Arnaud Raynouard, Comment gagner facilement vingt places au classement "Doing business," La Tribune, 14 January 2009, available at http://www.la tribune.fr/opinions/20090113trib000330948/comment-gagner-facilement-vingt-placesau-classement-doing-business.html.

23. As explained in the May 2009 newsletter of the Foundation, a selection of articles published in the most well-known journals dealing with L\&E will be reviewed and the reviews, written in English and in French will be posted on a regular basis, following the initial publication. The first essays include articles published in Global Jurist (Berkeley Electronic Press), the journal of Law, Economics and Organizations (Oxford University Press) and the Stanford Law Review (Stanford University).

24. Among a large number of publications, see Bertrand du Marais, Didier Blanchet, Anna Dorbec, supra note 20; Bertrand du Marais, Mesurer le droit? Ou plutôt l'évaluer?, Quelques réflexions sur les limites méthodologiques des rapports Doing Business, 2006 InT'L Bus. L. J. /Revue de droit des affaires internationales 675; Blandine Mallet-Bricout, Libres propos sur l'efficacité des systèmes de droit civil, 2004 
ments used under French law; for others, the reaction was more general and based on principle. It is impossible to give a complete account here, but the criticism emerging from the Association Henri Capitant des Amis de la culture juridique française needs to be mentioned in greater detail as it goes to the very root of this question: is law an economic contest?

\section{The Critical Analysis Developed by the Association Henri Capitant des Amis de la culture juridique française}

The Association Henri Capitant published two collective works on the Doing Business reports, one written by French academics, attorneys, and notaries, ${ }^{25}$ another by non-French members of the Association, i.e., academics and judges from a wide range of jurisdictions: Belgium, Brasil, Bulgaria, Chile, Colombia, Spain, Greece, Guatemala, India, Italy, Lebanon, the State of Louisiana, Morocco, Mexico, Panama, the Netherlands, Puerto Rico, Quebec, Romania, Switzerland, Syria, Tunisia, and Vietnam. ${ }^{26}$ The authors are most critical of the Doing Business methodology. We will provide a somewhat detailed account of the first book here, for two reasons: first, this volume clarifies the reaction of French lawyers upon reading the Doing Business 2004 report; second, one of us took an active part in writing this collective work and therefore shares the arguments presented in it.

The volume first questions the methodology used in the reports. ${ }^{27}$ Chapter I criticizes the fact that the authors of the World Bank report, who are economists, not lawyers, have a perception of law which is distorted by the use of econometric methods based on the analysis of economic development factors. ${ }^{28}$ Although it initially appeared to be scientific in nature, the aim behind the study emerged to be a biased promotion of common law countries to conquer the law

Revue internationale de droit comparé 865; Michael Haravon, Le rapport Doing Business 2007 de la Banque mondiale: le mirage des classements pour mesurer l'efficacité de la justice civile, 2008 JurisClasseur Périodique, édition. Entreprises I.2369; Michael Haravon, Doing Business 2009: mesurer l'efficacité des faillites? 2009 Recueil Dalloz 244; Janine Berg, Sandrine Cazes, Comparer et classer les droits du travail nationaux: les limites des indicateurs Doing Business, 2008 Revue de droit du travail 264; Claude Menard \& Bertrand du Marais, Can We Rank Legal Systems According to Their Economic Efficiency?, 26 WASH. U. J.L. \& PoL'Y 55 (2008).

25. François Barrière, Philippe Didier, Philippe Dupichot, Bénédicte FauvarqueCosson, Michel Germain, Michel Grimaldi, Jacques Pourciel, Bernard Reynis, Jacques Terray.

26. Vol. 2 Association Henri Capitant des amis de la culture juridique française, Les droits de tradition civiliste en question. A propos des rapports Doing Business (2006). Adde Revue de Droit des Affaires, $\mathrm{n}^{\circ} 3$, 2005, éd. Université Panthéon-Assas (with the imput of students from the Magistère in business law of the University of Panthéon-Assas, Paris II, followed by that of practicing lawyers and professors).

27. See, in particular, for a study of each chapter, op. cit. p. 35 and following.

28. See title I headed "Introduction critique à la méthode des rapports" (Critical presentation of the methodology adopted in the reports), p. 13 and following. 
market at the expense of the other great legal family, referred to as the French civil law tradition in the reports. All comparatists will immediately see that the obviously dichotomous vision of this relationship-common law versus French civil law tradition-upon which these reports are based, fails to account for cases of hybridization which enable the coexistence of both traditions within one and the same legal system. ${ }^{29}$ Comparatists know well that the law is constantly undergoing processes of internationalization and Europeanization. ${ }^{30}$ Chapter II examines numerous other errors, some of which were corrected in the 2005 report.

Chapter III then lays out the advantages of the French civil law tradition. This may sound chauvinistic or parochial, but one has to see this defense in its context: but for the violent attack on the part of the World Bank, it would not have been necessary to insist on demonstrating that French law (or the French civil law tradition) is structurally capable of encouraging economic prosperity; that the model is perfectly suited for export; and that it even boasts a considerable advantage in this respect: it is codified. ${ }^{31}$ As pointed out in the book, codification is now frequently used even in common law systems, at least in the form of official or private compilations, Codes, Revised Laws or Consolidated Laws. This phenomenon attests to the necessity of codification and significantly narrows the gap artificially created by the Doing Business reports between civil law and common law traditions. The claim that written sources of law might not be as flexible as case law is discredited on the one hand by the rigidity of precedent (albeit softened and tempered by a case by case evolution) and on the other hand, by quasi permanent legislative reform. In fact, it is the short life expectancy of new laws which attracts complaints,

29. Compare with Blandine Mallet-Bricout, Libres propos sur l'efficacité des systèmes de droit civil, 2004 Revue internationale de droit comparé 865. See, generally, Vernon V. Palmer, Mixed Jurisdictions Worldwide: The Third Legal Family (2001).

30. On the similarities between English and French law and for a renewed vision as to the differences frequently pointed out, see Basil Markesinis, Constructions de systèmes et résolution de problèmes concrets. Occasions manquées et naissantes pour une convergence méthodologique entre le droit français et le droit anglais, 2005 Revue trimestrielle de droit civil 47, published in English as French System Builders and English Problem Solvers: Missed and Emerging Opportunities for Convergence of French and English Law, 40 Tex. InT'L L.J. 663 (2005).

31. Xavier de Roux, Le Code civil reste un outil privilégié, La Tribune, 18 March 2004: "Le Code civil crée d'abord la sécurité juridique, il sait s'adapter aux évolutions de la société. Facile à lire, clair dans ses énoncés, il est par nature même d'essence démocratique. La méthode qu'il utilise, non seulement a fait ses preuves, mais devrait rester pour le législateur un modèle. Il est désormais accessible sur Internet en anglais et en espagnol. Il doit rester pour le juriste et pour longtemps l'outil privilégié" [The Civil Code creates first of all legal security, it adapts to the evolution within society. Easy to read, clear in its drafting, it is by essence democratic. The methodology it uses has not only proved to be effective, but should remain a model for the jurist. It is now available on the internet in English and Spanish. It must, for the jurist, remain the tool of choice, and this for a long time.]. 
rather than their ossification. In addition, French judges, like so many others, have the power to interpret the law, and even to circumvent it where necessary. In reality, the power of the common law (more precisely U.S. or English law) can be explained by certain extrinsic factors: the liberalism of the American economy, the dominant role of the English language throughout the world, the success of Anglo-American law firms, whilst the French legal profession, split as it is into avocats, notaires, conseils juridiques, etc., finds itself at a disadvantage; ${ }^{32}$ in addition, there is also the policy of exporting American law with its strong influence on institutions. Note that in light of the current global financial crises, these factors have proved to be more ambivalent than previously assumed.

Chapter IV criticizes the very premise of the Doing Business reports. The main objection is that law is not a mere "favorable regulatory environment." Therefore it is wrong to evaluate the quality of a particular legal system only in the context of economic prosperity enjoyed by the society in which it operates. Consequently, jurists should not hand over their profession to economists who, excited by the idea of mathematical assessment, advocate universal legal standardization, as in the "one size fits all" approach. The law of the richest is not necessarily the best.

As explained in the work of the Association Henri Capitant, French law is humanistic in nature, protecting the rights of the individual. It has played a key role in Europe and throughout the world in the dissemination of fundamental human rights. The Civil Code has inspired the belief that the law is there, first and foremost, to protect social peace and the citizens' freedom and will. ${ }^{33}$ For countries wishing to re-establish order and social peace, especially for those wanting to emerge from an oppressive regime, the Civil Code continues to be an invaluable model, able to provide a society with the "legal structure necessary to its operation." 34 The volume ends with a plea for legal diversity (one size does not fit all) and with the refusal on the part of the authors, in and outside of France, to reduce law to a "favorable regulatory environment." 35

Aside from these academic reflections upon the merits of the civil law tradition, the French stakeholders ensured that a dialogue opened with the World Bank team responsible for these reports to

32. See, on this point, "L'influence internationale du droit français," Rapport du Conseil d'Etat, supra note 8, at 75.

33. On "the spirit of the Code Civil," see Jean Carbonnier, Droit civil, Introduction $\S 74$ (2004); John Bell, Sophie Boyron \& Simon Whittaker, Principles of French LAW 1-10 (2d ed. 2008).

34. Pierre Delvolvé, Conclusion générale, in II Journée d'étude à l'occasion du bicentenaire du Code civil, Le rayonnement du droit codifié, Journée du 26 novembre 2004. 369, 380.

35. ("Environnement réglementaire favorable"), Les droits de tradition civiliste en question, supra note 7, 126. 
suggest improvements to their methods, their questionnaires, and modification of certain indicators. Because they were drafted by economists and because the greatest influence in economics emanates from the United States, these questionnaires appeared skewed in favor of the common law from the start. The responses to these questionnaires also raised some criticism. They are sometimes inaccurate, provided by unidentified persons or by persons who are unaware of the latest reforms. Moreover, with regard to certain areas, the sample of persons responding was insufficient; for example, a large global firm provided answers for all countries to taxation questions. Another matter of concern is the way in which the information is processed by the World Bank team. Indeed, it is difficult to ascertain to what extent reforms were actually taken into account on a country by country basis. In addition, certain misleading assertions have never been corrected. The most obvious one pertained to property transfer: the first response which was very detailed described the entire process at great length which is why, as observed by the notaries, France was so badly placed in this regard. More generally, the choice of indicators and their limited number have been criticized as failing to reflect the ability to "do business," because they neglect the favorable socio-economic environment which encourages companies to set up in France.

Five years after the publication of the first Doing Business report, the French are no longer alone in their battle against the unbending approach to economic and political comparability. First and foremost, the Independent Evaluation Group (IEG) report published in 2008 by the World Bank has attracted criticism and recommendations along the same lines as the ones expressed by the French since the very beginning of the Doing Business saga. ${ }^{36}$ The evaluation recommends more transparency, reliability, and diversity with regard to the informants. Changes are also suggested for the process of the collection and use of information as well as corrections of published data and modifications to the methodology. Furthermore, the IEG report recommends that Doing Business also measure improvements other than only those to regulatory costs and burdens, "which is only one dimension of any overall reform of the investment climate."37 Moreover, in other countries and, particularly in the United States, voices can be heard denouncing certain indicators, espdf.

36. Http://siteresources.worldbank.org/EXTDOIBUS/Resources/db_evaluation.

37. IEG Report, Doing Business: an independant evaluation, Taking the measure of the World Bank-IFC doing Business indicators, sp. xvii and xxii (2008), available at http://web.worldbank.org/WBSITE/EXTERNAL/EXTOED/EXTDOIBUS/0, content MDK:21679357 pagePK:64829573 piPK:64829550 theSitePK:4663967 isCURL:Y, 00.html. 
pecially in the labor law sector. ${ }^{38}$ Indeed, by using the Employing Workers Indicator (EWI), the best scores were given to countries that have the least amount of labor regulation in areas such as minimum wage, maximum weekly work hours, requirements for prior notice in case of layoffs, and severance pay. Thus, there has been no lack of criticism in many parts of the world. What ultimately makes the French reaction unique however, is that it was swift, widespread among legal professions and that it soon led to a fresh assessment of the merits of law and economics.

\section{The Impact of Law and Economics in France}

Aside from the objections to the methodology used by the authors of the Doing Business reports, there is the question of the impact of economic analysis in France, and more specifically on comparative law. The issue is not new. However, the way in which the World Bank has resorted to tools of economic analysis in order to assess and rank the different systems of law prompted a new kind of debate. The economic methodology raised new doubts and even opened questions about the relevance of the methodology traditionally employed in comparative law.

\section{A. The Relationship between Law and Economics}

Law and economics have not always been treated as two incompatible fields of study in France. Jurists have long welcomed economic science: in 1877 economic science was introduced as a subject into the French law curriculum ${ }^{39}$ and the teaching of management and economics within law departments boasts an even stronger presence today, moreover, an increasing number of jurists in France have an interest in an interdisciplinary approach. Academics

38. Criticism on the part of the trade unions was also strong. See ITUC, World Bank's Doing Business Makes Unsubstantiated Assertions, Rewards Countries, M2 Presswire, 10 September 2008; Trade unions condemn Doing Business 2008: Once again, World Bank gives excellent "Employing Workers" scores to countries that violate workers' rights, M2 Presswire, 25 September 2007. Indeed, by virtue of this Employing Workers Indicator (EWI), the best scores were given to countries that have the least amount of labor regulations in areas such as minimum wage, maximum work hours, required advance notice for layoffs, and severance pay. The reports also incorporated a "Social Contributions and Labor Taxes" indicator that actively discourages the provision of social protection programs by rewarding countries with the lowest level of mandatory employer contributions to non-wage benefits such as pension plans, healthcare, unemployment insurance, and maternity leave. On April 28, 2009, the Bank announced the suspension of the Employing Worker Indicator (EWI) and a commitment to reexamine and revise both the EWI and the "Paying Taxes" Indicator in its annual country-ranking exercise.

39. A decree of 26th of March 1877 made economic science a compulsory subject. See Yves Chaput, Droit et/ou Economie francophone, la quadrature du cercle par le GDR 2327, 16 Revue Internationale de droit economique 125, 129 (2002). 
agree that economic aspects should not be underestimated when analyzing law as an instrument to shape social and economic life. ${ }^{40}$

Yet, economic arguments are accepted only to a limited extent. French academics generally have considerable reservations about the idea of economic performance "in and of itself, at any price, and for the short term." 41 In practice, judges do not ignore this aspect. ${ }^{42}$ From an economic agents' perspective it becomes a priority, with the need to be protected by law guaranteeing the freedom to do business. ${ }^{43}$ Finally, far from being rejected by French academics, ${ }^{44}$ the question of economic efficiency of the law remains at the forefront of the profession's concerns. This is also true also for the legislator who is in constant search of the most favorable solutions for the problems of economic life. ${ }^{45}$

40. In particular, François Zenati, Le droit et l'économie au-delà de Marx, in Droit et Économie, 37 Arch. Phil. Dr. 121 (1992), in which the author demonstrates the narrow links which exist between Law and Economics in modern societies.

41. Ass. Capitant, Les droits de tradition civiliste en question, supra note 7 , at $\mathrm{n}^{\circ}$ 112, p. 127; Marcel Fontaine, Fertilisations croisées du droit des contrats, in Le contrat au début du XXIè siècle, Études offertes à Jacques Ghestin, LGDJ, 2001, p. 347 and following, esp. $\mathrm{n}^{\circ}$ 8: "Si elle est perçue comme un instrument additionnel, non exclusif, de l'analyse juridique, l'approche économique présente le plus grand intérêt" ("If it is seen as an additional, but not exclusive tool of legal analysis, then the economic approach is most interesting"). Academics sometimes refuse to consider efficiency to be a concept, see Arnaud Raynouard, Faut-il avoir recours à l'analyse économique du droit (AED) pour assurer l'efficacité économique du droit?, 2008 Revue de la Recherche Juridique-Droit Prospectif 2509, 2510, available at http://www.crdp. umontreal.ca/fr/publications/ouvrages/Revue_recherche_juridique.pdf.

42. The notion of "politique jurisprudentielle" (judicial policy) appeared in France as "what shows the adaptation of case law to the economic and social constraints," Guy Canivet, Nicolas Molfessis, La politique jurisprudentielle, in La création du droit jurisprudentiel, Mélanges en l'honneur de Jacques Boré 79 (2007), esp. $\mathrm{n}^{\circ} 8$. In practice, the criterion of efficiency in private law appears more and more often as a useful tool for the judge, particularly with regard to the interpretation of contracts, or to decide whether a decision by corporate managers conforms to the interest of the company. See Anne-Julie Kerhuel, L'efficience stratégique du contrat d'affaires $\mathrm{n}^{\circ} 112 \mathrm{~s}$. (PUAM 2009); see also Bruno Oppetit, Le rôle du juge en présence des problèmes économiques en droit civil français, in XXII Le rôle du juge en présence des problèmes économiques 185, 186 (Ass. Capitant ed., 1970).

43. The freedom to do business is a principle of constitutional value, as it was declared in somes decisions of the Conseil Constitutionnel, for ex. Cons const. 12 janvier 2002, $\mathrm{n}^{\circ}$ 2001-455 DC, Loi de modernisation sociale, considérant $\mathrm{n}^{\circ} 49$; La Semaine Juridique édition Entreprises, 27 mars 2003, $\mathrm{n}^{\circ} 492$, p. 558, note Julien Raynaud. On the influence of this freedom upon other principles like contractual liberty, see Marie-Anne Frison-Roche, Thierry Revet (dir.), Libertés et droits fondamentaux, 2007, 13ème éd., Dalloz, coll. CRFPA, p. 711 s., Indeed, contractual freedom often is protected quite specifically.

44. In particular, colloquium on "L'analyse économique du droit: Impérialisme disciplinaire ou collaboration scientifique?", 16-17 May 1986, Aix-en-Provence, published at Revue de la Recherche Juridique-Droit Prospectif, 1987, p. 409 and following, See also Raynouard, supra note 41, La Semaine Juridique édition Entreprises p. 2511.

45. The idea of making French law more attractive has been an impetus for recent reforms. For example, the Loi de sauvegarde des entreprises (loi $\mathrm{n}^{\circ}$ 2005-845) of July 26,2005 designed to improve the anticipation of economic difficulties, the Law on the modernization of the economy, ( $\left.{ }^{\circ} 2008-776\right)$ of 4 aout 2008 and the Reform project 
Looking at the Law and Economics movement in the United States in the 1960s as founded especially by Coase and Calabresi, one has to acknowledge that in the beginning, it did not attract the support of French jurists. The French hesitation arose mainly from the inherently utilitarian perspective ${ }^{46}$ adopted by the movement. This perspective is incompatible with the French view of law as a science destined to serve man more generally and to promote social harmony. In fact, French academics have by and large been reluctant to accept anything economically useful as therefore fair and, a fortiori, to accept that the economic analysis of law should have a normative impact. The idea of the economic performance of law, which underpins an economic analysis, thus stands in contrast to the humanistic approach, characteristic of civil law systems. ${ }^{47}$

Nonetheless, the economic analysis of law continues to spread its influence and authors of that school are keen, more so today than before, to establish a real dialogue with traditional jurists. ${ }^{48}$ Such an exchange can only benefit both sides, so long as the specificity of each area and of its mode of reasoning is preserved. French academics have generally been far more accepting of Law and Economics theories when they were presented as a descriptive approach rather than a normative claim. ${ }^{49}$ Normative claims lead to an inversion of the order of values and place economic criteria ahead of the essential element of the law which is, from a traditional French perspective,

relating to Contract Law, which is being considered at the moment, are all trying to improve the attractiveness of French Law.

46. The utilitarian aspect results from the fact that the efficiency factor is seen as the main characteristic. The principles of social justice are therefore subordinate to maximum economic usefulness. In this respect, see Jacques Ghestin, L'utile et le juste dans les contrats, 1982 Recueil Dalloz 1, in which the author demonstrates the limited role of one particular aspect of usefulness of a contract within the general theory, according to which the obligational aspect is based on the initial consent of the contracting parties.

47. One can note that, conversely, economic analysis is more acceptable as a normative function in the common law systems, in which "it provides a normative standard in the absence of precedents and helps to structure the vast body of case law," Florian Faust, Comparative Law and Economic Analysis of Law, in THE OxFORD Handbook of Comparative Law 837, 858 (Mathias Reimann \& Reinhard Zimmermann eds., 2006).

48. The recent work of Ejan Mackaay, Stéphane Rousseau, L'Analyse économique du droit (Dalloz 2008) generated a real debate and resulted in renewed interest, among academics, to discuss the question of the economic stakes in law.

49. Such a standpoint corroborates the positive approach adopted by Posner, see Marc Deschamp and Frédéric Marty, L'analyse économique du droit est-elle une théorie scientifique du droit?, Revue de la Recherche Juridique-Droit Prospectif, 2008-5, p. 2541, available at http://www.crdp.umontreal.ca/fr/nouveautes/index.html, esp. 2550 . In the first case, the economic analysis has an essentially descriptive role. In other words, the economic results are merely an indicative by-product for the legislator. In the second case, the influence of the economic analysis is stronger to the extent that the economic criterion becomes an ingredient to be taken into account when creating a rule. More generally on the distinction between the positive and normative approach, see Faust, supra note 47 , at 839-44. 
the search for fairness. In its descriptive dimension, however the Law and Economics school can provide a valuable contribution to legal studies. The search for economic performance is indeed an important factor in the determination of whether a law is fair and balanced; in the same way, economic analysis can act as a particularly useful tool in the study of comparative law.

\section{B. The Impact of Economic Analysis on Comparative Law}

The tools of economic analysis can be useful, even necessary, in the comparative study of legal rules. On the one hand, they provide elements of analysis which allow one to take the economic stakes underpinning any organization into account. In a context of increasing international competition, the integration of the economic dimension into comparative legal studies is almost unavoidable. Internationalization and the weight of global competition have become so important that it is crucial for countries to determine which conditions are the most favorable for their economic development. Economic performance, including that of legal systems, has become a decisive factor in defining their international influence. After the development of forum shopping in the field of private international law, and also of intense tax competition ${ }^{50}$ economic rivalry now affects all systems of law globally. On the other hand, the statistical method proves to be a simple and fast tool to compare different systems of law and their ability to meet the demands of a competitive business world. The complexity of the traditional comparative method contrasts starkly with the almost disconcerting simplicity of the mathematical criteria driving an economic analysis. ${ }^{51}$

Under these conditions, there could be a strong temptation to substitute the economic analysis of law for the more traditional comparative approach. Yet there is a rub: the economic analysis suffers from a number of deficiencies ${ }^{52}$ and the traditional comparative method is itself useful, even necessary, to complement the economic approach.

50. See, in particular, Jacques Spindler and Henri Isala, L'ordre concurrentiel et la fiscalité, in L'ordre concurrentiel, Mélanges en l'honneur d'Antoine Pirovano 167 (éd. Frison-Roche, 2003); Jeffrey Owens, La fiscalité dans le village planétaire, Brochure des affaires fiscales, OCDE, 2000, p. 11-12.

51. See Ralf Michaels, The Second Wave of Comparative Law and Economics?, U. Toronto L.J., 59, esp. 209 and 212 (2009), and the response of Gillian Hadfield, The Strategy of Methodology: The Virtues of being Reductionist for Comparative Law, U. ToRONTO L.J. 59, esp. 228 (2009). The challenge of complexity in the modern world has been treated, from a philosophical point of view, by Edgar Morin, Introduction à la pensée complexe, éd. ESF, 1990.

52. Indeed, the economic criterion usually, if not always, shows the limits of Economic Science, which estabishes criteria, conceptualizes and simplifies to the extreme while forgeting important aspects which may be much more complex. Among the numerous publications, from both economists and jurists, see Alain Bernard, Law and Economics, une science idiote?, Recueil Dalloz 2008, p. 2806 and following. 
The more qualitative perspective of the comparative approach enables the quantitative economic analysis to be refined and allows the study of the different systems to reach greater depth. First, the functional approach to comparative law identifies the various rules, whether procedural or substantive, which fulfil an economic objective. The comparatist, in this way, provides the economist with the basic subject matter for his study. ${ }^{53}$ An economist's assessment can only be meaningful once all the different legal means of reaching a particular result have been considered. The comparatist thus contributes to an increased analytical capacity of the economist and renders his analysis more credible. Second, the comparatist also intervenes $a$ posteriori, to round out the economic analysis, e.g., by explaining the reasons for differences of assessment which may occur. ${ }^{54}$ In addition, a more holistic approach may temper the mathematical harshness of a purely economic view. It is a fact that law is intimately linked to the cultural particularities of a country and must consider the complex reality of man living in society. That is why any comparison, even if it is more specifically directed at the performance of a system, requires that the philosophical and socio-political dimensions as well as the paradigmatic values of the legal system be taken into account. ${ }^{55}$ Economists could significantly improve the quality of their research by paying more attention to cultural detail.

Bearing this in mind, it will come as no surprise that the legal origins thesis should be widely contested from a French comparatist point of view. Aside from the fact that it is based on an assessment which is mainly purely economic, and therefore incomplete, it at best establishes a correlation between global economic development and the respective legal system, be it civil law or common law. The correlation however, does not establish a causal link-it merely presupposes one. Thorough comparative analyses have already pointed out the deficiencies in the assertions put forward.56 Moreover, the legal origins thesis bases its analysis on a classification of

53. Faust, supra note 47 , at 850 .

54. Some differences relate to the nature of the procedural or substantial rules used to reach a particular result. For an example on the issue of integrating unforeseen damages into the amount of reparation, see Faust, supra note 47, at 854 .

55. The acknowledgment of this fundamental aspect associated with any legal system has led a number of authors to reject the idea of a possible competition between the different legal systems. See Darrois Report, available at http://www.justice. gouv.fr/art_pix/rap_com_darrois_20090408.pdf, esp. 7; Pierre Legrand, The Impossibility of "Legal Transplants," 4 MaAstricht Journal of European and Comparative LAw 111 (1997); Arnaud Raynouard, Le droit dans une économie mondialisée de la connaissance, 32 Revue Lamy de droit des affaires 81, 82 (2008). However, the idea according to which the differences in culture are enough to ruin the recognition of a "legal market" or business, reduces the importance that is sometimes given to an exclusively economic analysis.

56. For example, the difference in perspective, essentially causalistic in civil law countries and consequentialist in common law systems, has sometimes been given as a reason for the advantage granted to the latter by the legal origins thesis. 
legal systems divided into legal families which is now by and large outdated. The globalization of law and its changing boundaries require a new approach to new analyses. ${ }^{57}$

Yet, the attention which the legal origins thesis has attracted will necessarily have an impact on comparative law. The Thesis has demonstrated the importance of including economic criteria and this realization may lead to an improved and more adaptable comparative view. In other words, comparative law should develop into a more encompassing and practical science, truly prepared for action ${ }^{58}$ and ready to deal with the problems created by an increasing economic globalization.

This awareness will generate new activity in comparative law, all too often considered to be an "ancillary discipline" in France. ${ }^{59}$ Between the supporters of a normative approach to economic analysis and the supporters of a complex comparative law approach, ${ }^{60}$ the attention comparatists are now paying to economic analysis should allow a meeting of the minds and revitalize in comparative law a more practice and reform oriented study of the evolution of legal rules and institutions.

57. Jean-Louis Halpérin, Profils des mondialisations du droit (Dalloz 2009).

58. As described already by Edouart Lambert, General Report, in I Congrès international de droit comparé, procès-verbaux des séances et documents 3, 35 (1905), cited by Bénédicte Fauvarque-Cosson, Development of Comparative Law in France, in THE OxFORD HANDBOOK OF Comparative LAw, supra note 47 , at 35,43 . Whilst traditionally comparative law seldom calls upon economics, some authors have condemned this deficiency. See, in particular, Anthony Ogus, Economic Analysis and Comparative Law, in D'ici, d'ailleurs, harmonisation et dynamique du droit, Mélanges en l'honneur de Denis Tallon 169, esp. 171 (éd. SLC, 1999).

59. Xavier Blanc-Jouvan, Prologue, in L'avenir du droit comparé 10, 15 (2000); Fauvarque-Cosson, supra note 58, at 37.

60. Based on social theory and excluding any mathematical modelization, seen as purely artificial, see Pierre Legrand, Econocentrism, 59 U. ToRonTo L. J. 215 (2009); more generally Pierre Legrand, Le droit comparé (3d ed. 2009). 
